\title{
APPLICATION OF PATTERN OF ISLAMIC STATE REVENUE POLICY TO IMPROVE THE ABILITY OF INDONESIA'S FISCAL
}

\author{
Any Setianingrum ${ }^{1}$
}

\begin{abstract}
Application of Pattern of Islamic State Revenue Policy to Improve the Ability of Indonesia's Fiscal. The aim of this study is to analyze the possibility of Islamic state revenue to improve the ability of Indonesia's fiscal. This thing is important in the way to diversify the fiscal instruments in Indonesia. The result shows that several Islamic revenues instruments still relevant to applied in Indonesia, exclude the ghanimah and Jizya. But, it is necessary to adjust the nomenclature and connectivity with state financial regulations. The application does not have to be exclusive and labels associated with Islam, but should be more focused on the exploration of universal values and utility, which is inherent in all of Islam income instruments.
\end{abstract}

Keywords: fiscal instruments, historical analysis, case study

\begin{abstract}
Abstrak. Aplikasi Kebijakan Pendapatan Islami Untuk Meningkatkan Kemampuan Fiskal Indonesia. Tujuan dari penelitian ini ialah untuk menganalisis kemungkinan penerapan kebijakan pendapatan pada Negara Islam dalam meningkatkan kemampuan fiskal Indonesia. Hal ini penting dilakukan dalam rangka diversifikasi instrument fiskal di Indonesia. Teknik analisis yang dipergunakan dalam penelitian ini ialah teknik analisis historis dan studi kasus. Hasil yang didapat menunjukkan bahwa instrumen pendapatan Islam masih relevan untuk diterapkan pada pemerintahan di Indonesia, kecuali ghanimah dan Jizya. Akan tetapi aplikasi instrument pendapatan pada Negara muslim kontemporer saat ini memerlukan penyesuaian nomenklatur dan keterkaitan dengan regulasi yang berlaku. Aplikasi tersebut tidak harus bersifat eksklusif dan dikaitkan dengan label-label Islam, tetapi harus lebih focus terhadap eksplorasi nilai dan utiliti yang bersifat universal, yang sudah melekat pada semua instrument pendapatan Islam.
\end{abstract}

Kata Kunci: instrument fiskal, analisis historis, studi kasus

First draft: February, $5^{\text {th }}$ 2015, Revision: March, 15 ${ }^{\text {th }}$ 2015, Accepted: April, $2^{\text {nd }} 2015$

${ }^{1}$ Doctoral Students at Airlangga University, Surabaya

Email: anysetianingrum@yahoo.com 


\section{Introduction}

The management of government finances is also widely expected to greatly affect the domestic economy, the private sector and the overall economy. Moreover, in the government's financial management policies are also attached to the functions of public finance policy, namely the function of allocation, distribution and stabilization. Effectiveness and efficiency of the passage of these functions depend on how strong the system is applied to the financial management of central and local government. In other words, the successful handling of market failure, the need for public goods and externalities factors handling by the government to be very dependent on how the government's financial management is executed. Domino effect of government financial management is also very broad, covering the role of stimulator, facilitator, coordinator and entrepreneurs in regional development, which can boost growth and equitable income distribution. While at the same time there are still many problems that arise in the government's financial management system.

Some real problems are found from the results of various research areas in Indonesia's financial pattern is, most of the proposed program of results from Musrenbang (consensus development plan), followed by all elements of society can't be realized because of limited state funds. Results interview with the Mayor of Bekasi (2014) stated that the 30\% of new development programs that can be handled by the state budget. In the other words, there are $70 \%$ of programs and activities that should be funded by the budget, but can't be realized because of region fiscal constraints.

Other real problems that are found by several studies almost all local governments in Indonesia have the same problems that have a low degree of fiscal decentralization (Kuncoro, 1995). This indicates the weakness of the financial management area and the need to improve strategies and seek new breakthrough in terms of financial management. The foregoing is also confirmed in research Amri in Halim (2012), explained that the management of revenue and expenditure management is an important part in the management of government finances. However, until now attempt to explore the sources of revenue still has many obstacles, both in terms of limited financial resources itself and in terms of capabilities and management systems as well as administration (Dewi in Halim, 2001). In fact, development needs still need to be accelerated and enlarged in order to improve the welfare of the community. But in fact, the construction still has many obstacles and challenges are not small.

The presence, the entire classical problem is still not ideally show local financial management system that is capable of moving the revenue potential 
and development programs needed optimum community. The main cause of this problem is the allocation of limited funds both from local government sources and the central government. Therefore, local and central governments must still required to be able to look for alternative ways so that development can be further expanded and enlarged. Then the solution is the need to explore funding, including the conduct of innovation creation of resources for regional and central growth.

Since the multidimensional crisis that hit Indonesia has alerted us all of the need for reinforcement of the paradigm and economic activities based on moral and ethical. So that the current era is needed to evaluate alternative approaches as well as strengthen existing economic structure. The implication in the current era is needed to evaluate alternative approaches as well as strengthen existing economic structure, including in areas such as public financial management. Alternative paradigms that are currently being taken into account by economists are Islamic economic system. Economist belief that Islamic economic system is capable of being a favored alternative system is supported also by the Islamic financial performance that proved to have better durability in a period of economic crisis that happened in the world since 1998.

In the perspective of Islamic-based financial system, potential sources of revenue in each region in Indonesia are still a lot and not maximized empowered. The practice of public finances during the reign of the Prophet Muhammad and the first four caliphs had income instruments and mechanisms that have been proven history, able to function well in the distribution of income, economic growth while socio-economic stability. This fact is supported by the Western economist, Adam Smith, in his book The Wealth of Nations (1976), which makes two classes of countries, namely the developed and underdeveloped countries. And by Smith (1976), Medina in Mahomet and his immediate leadership successors (Muhammad and the first four caliphs) the majority of the livelihoods of its people are traders classed as a developed and prosperous country at the time. Based on the track record, in this study will be an analysis of the management of incomes policy at the time of the Prophet Muhammad and the first four caliphs to be a reference as well as how to dig and revitalize their income instruments for strengthening the financial system in the present area.

Based on the description above background drafted this paper, by using qualitative research methodology, the historical analysis methodology and case studies conducted from June to January 2014. The historical analysis methodology used to analyze and explore the instruments and mechanisms for government financial management pattern at the time of the Prophet Muhammad and the first four caliphs. The case study methodology is used to analyze and explore how and 
why patterns of local finance and mechanisms implemented under the current structure. Case studies carried out in the Local Government City of Bekasi, as a representation of local government in Indonesia.

\section{Literature Review}

Below will describe some of the results of research on financial policy that occurs in the central and local governments in Indonesia. Before analyzing the results of financial management at the local government level, will be examined in the study at the national level first. However, either directly or indirectly, a financial policy at the national level will give effect to the policy in the region. The discussion on the issue, starting on tax policy in the Republic of Indonesia, which done by Surjaningsih (2012), the research found there is a co-integration relationship between government spending and taxes on output in the long run. In the long term taxation, there is a positive impact on economic growth while government spending is doesn't give an impact. Short-term adjustment shows that the shock of the rising in government spending has a positive impact on output while shock negative impact of tax increases. More dominant effect of government spending on output in the short term than the show is still quite effective tax policies to stimulate economic growth, especially in times of recession. While the increase in government spending led to a decrease in inflation, while tax increases lead to an increase in inflation. This study also showed the absence of discretionary fiscal policy conducted by the government. From research Surjaningsih (2012), can be considered for local governments to regulate taxation and spending policies, which have a different impact in the short and long term growth and macroeconomic indicators in general.

Other studies are useful to complement the considerations in determining the pattern of regional finance is the state budget process in Indonesia. Indayani research results (2006) found that: first, outside of routine spending of foreign debt was under pressure because they have to make sacrifices for the payment of foreign debt increased tendency to be from year to year. Second, direct development budget even more depressed because domestic revenues also have to be sacrificed for routine expenditure, which is dominated by foreign debt payments. Third, the position of the government savings is actually quite large, at least seen from the existing economic conditions. Indayani (2006) show reminiscent of the government that in addition to issues of taxation and spending policies will affect the macroeconomic indicators in general.

Looking at the results of the research described above, the various problems that accompany financial management, the improvement of income and expenditure 
policies become very urgent. One of the most pressing policies to be improved is the taxation policy as wide domino effect. It is as stated by Yudhoyono (2010), that tax policy should be improved to make to be more fair because it involves economic policy and fiscal policies in general. Not optimal tax administration Indonesia caused by lack of clarity in the direction of development and the achievement of the ideals of the tax. As a result, the tax administration system becomes very weak. This is what makes many people take advantage of the tax for the benefit of themselves and each group (Commission, 2014).

After knowing the results of research on financial policy at the national level in outline, the following will describe the extent of the challenges and obstacles in financial management in the various regions in Indonesia to provide an overview, information and inventory issues as a preliminary study of the practice in the field. In terms of financial management area there are several things that must be considered, related to Law No.32 / 2004. The area has a larger role in managing local financial. This condition is an opportunity for local government to demonstrate its ability to manage finances without interference from higher levels of government (Yunasman in Halim, 2012). Below are some studies that explain the multiplicity and complexity of the challenges and constraints.

In terms of financial expenditure areas, the results Amri in Halim (2012), found that the lack of planning expenditures will eventually bring up the possibility of under-financing or over-financing, which all affect the level of efficiency and effectiveness of the work units of local government. From the results of previous studies as described above, found many factors that influence the effectiveness of revenue and expenditure policies of local governments. These factors are policies covering taxation revenue and average revenue is still low, government spending policies, the amount of debt payments, professionalism and human morality, both the executive and the judiciary.

\section{Methods}

To answer the question in this study used qualitative research methods. Consideration of the use of qualitative research approach is more complete data obtained, more in-depth, credible and meaningful so that the goal of this research can be achieved (Sugiyono, 2013). The strength of qualitative research lies in its ability to provide a textual description of the complex, in particular information that is the human side, such as behaviors, beliefs, opinions, emotions, and interaction between individuals. Qualitative methods are also effective in identifying intangible factors, such as social norms, socioeconomic status, gender rules, ethnicity, religion and the whole issue is not legible appearance. 
According Sugiyono (2007), Qualitative research is divided into three stages: first, stage description or the orientation phase, at this stage the researchers describe what is seen, heard and felt on the information obtained; Second, reduction stage, at this stage of research to reduce any information obtained to focus on a specific issue focus; Third, the selection stage, at this stage the researcher outlines the focus that has been determined to be more detailed and in-depth analysis. The research methods used on this research are the historical analysis and case studies.

In the analysis of historical, scientific history writing is required to generate explanations regarding the issues discussed. Explanation was obtained through the analysis. An important step in making a historical analysis is to provide a framework or frame of reference that covers a wide range of concepts and theories that will be used to make the analysis. Historical research is supported by theories reliable, is more accountable objectivity history of science itself (Kartodirdjo, 1988).

Case study is a research method that specifically investigates a contemporary phenomenon that is present in the context of real life, which is implemented when the boundaries between phenomenon and context is not clear, by using various data sources (Yin, 2003). Position theory constructed in a case study can be improve, supplement or enhance existing theories based on the latest developments and changes in facts. Stake (1995; 2005) and Creswell (1998), Yin (2003) argues that a case study using a variety of data sources to reveal the facts behind the cases studied. The diversity of data sources are intended to achieve the validity and reliability of the data, so that the results can be true. The fact is achieved through assessment of connectedness evidence from multiple data sources.

\section{Discussion}

Paradigm, concept and implementation of financial management in the Islamic government had a difference principle with conventional systems. The most fundamental difference is because in Islam there is a prohibition of usury and mechanisms of charity, donation, shadaqa, endowments and resource management must be adapted to the rule of the Al-Quran and al-Hadith. Among the differences in terms of revenue Islamic state is, charity is the main instrument for the Muslims, along with the poll and kharaj for non-Muslims, and supported by the social sector instrument donation, Sadaqah and endowments. While the tax levy in the Islamic state is not permanent, so that the government would seek to minimize taxes. It is different from the conventional system, which the tax became the main instruments of fiscal policy. Policies in the next income is the optimization of the social sector policies that donation, sadaqah and endowments as has mentioned above, in order to support the mandatory instruments such as zakah, Jizya and kharaj, which are not 
found in conventional economic system. The social sector instruments can be used as funding social welfare, defense and security and development under government management through Baitulmaal institutions.

Another difference was also found in government spending policies. Each source of income in the Islamic state has had certain rules of sharia in the distribution, which must be based on the Quran and Sunnah. With a distribution system that already has a special rule, the outline will suppress the emergence of irregularities over the allocation of funds and ensure the creation of distributive justice and prevent buildup of development results in the development of certain areas only. The mechanism of government spending was not found in conventional systems.

The pattern of future government revenue policy of the Prophet Muhammad and the first four caliphs had differences with the pattern of government financial policy in modern times is now based conventional economic system. However, both systems can't be compared, because of the situation and its condition at the components of the two systems are different can't be synchronized at this time. Until today, there is no standard formula of how the application of public finance in the modern Islam that refers to the government in time of the Prophet and the first four caliphs. Taking into account this reality, so in this paper, the analysis of comparison used is to explore aspects of the similarities and differences to the fullest, to analyze how the existing gap of the two systems, it can be concluded until the application prospect of financial instruments and mechanisms of government policy at the time of the Prophet Muhammad and the first four caliphs in today's modern times.

Tracking process undertaken to explore aspects of the similarities, differences and gaps against income instruments and how the enforcement mechanisms on both systems. From the comparative analysis of Islamic and conventional revenue policy, it can be seen the main points of similarities, differences and gaps, which is the result of the analysis of historical exploration and case studies on local government of Bekasi. Besides that, there is a difference both in the principles and mechanisms differ only in nomenclature. Differences in principle, in the management of the Islamic state, the instrument is a charity and ushr obligatory for the Muslim population, whereas for the non-Muslim population is kharaj, Jizya and ushr. Tax instruments in financial nomenclature Islamic state can be equated with kharaj and Jizya were only imposed on non-Muslim population, so it is not permanent, because if they converted to Islam no longer paid the taxes. Other instruments are equivalent to a tax is imposed nawaib only to Muslims who are very rich in the current size, in emergency conditions such as war and disasters. In principle, the tax imposed on the population of Muslims in Islamic countries used to fund a variety of needs and 
expenditure items that are required, the treasury condition no money / possessions. The obligation to pay the tax imposed only on those who had the ability to meet basic needs and complementary in kindness. While the tax instruments as a source of income in the Indonesian government imposed on private persons and legal entities of all mandatory, regardless of religion and is permanent.

The number of income instruments during the reign of the Prophet Muhammad and the first four caliphs who have the potential to be used as a reference and is applied directly as the original structure in the government of Indonesia, in today's modern times. Adoption of such instruments should not be exclusive, but still adapted to the regulations or existing State Finance Law, the nomenclature and mechanismadjustable. If there is an instrument that has great potential and the need to support regulations and laws should be the executive and the legislative act proactively.

There are several instruments that can be adopted and promoted by the Indonesian government. Zakah is very relevant instruments to be used as one source of local government revenue, considering that Indonesia is the largest Muslim country in the world. Nomenclature and regulatory constraints should not be a hindrance in attracting zakah, compared with the advantages and the benefits, so that these constraints must be overcome. Zakah has the potential of increasing the fiscal capacity of the government is still needed today. Zakah is widely also imply, directly or indirectly, will be able to: first, maintain a minimum wage of workers at the level of the distribution of zakah; Second, as a final shield for the economy so that no stagnation / consumption under crisis conditions. Third, pressing the accumulation of wealth, possessions forced turnover; Fourth, press the number of social problems: crime, prostitution, vagrants, beggars, etc; Fifth, guard aqidah; Sixth, in mathematical proofs, zakah not decrease consumption, because the next process will be neutralized by mustahik consumption.

Even during the reign of Umar bin Abdul Aziz under the Umayyad dynasty, in less than three years, the number of zakah payers continues is increases, while the number of recipients continues to decreases (Huda et al, 2012). As a result of excess surplus be used to subsidize private debt payments (private), social subsidies in the form of financing basic needs that are not the responsibility of the state as to bear the entire cost of weddings every youth who want to get married at a young age.

Al Arif (2010) stated that several positioning between zakah and tax, such as: first, only zakah that imposed for the society and the jizyah for the non-moslem. Second, zakah as the main sources of income, but the state can used the tax as additional income. Third, zakah and taxes is perfect subtition. So if the people had already paid the zakah, the individual is permitted to don't pay the tax. Fourth the 
zakah and tax must to be paid by the society.

While the instruments which have in common with the nomenclature of Indonesian government's income instruments, which can be used as a reference to correct and improve the performance of existing ones, such as: rikaz, kharaj, Jizya and $u s h r$. In handling rikaz or artifacts / richness of the earth, the state can get 20\%, far greater than the Indonesian government's acquisition of natural resource revenue sharing privately run both local and foreign so far. Tax form Kharaj calculated based on the results obtained from the use of the land. Calculations based kharaj could be a reference which is complementary as an alternative calculation technique considering the heterogeneous region. The Jizya or head tax for residents of non-Moslem that are able to pay, can be adopted to impose a tax on account of Indonesian citizens who put their funds abroad. Ushr or customs on goods entering and leaving the Islamic state imposed on Moslems who do not pay zakah on the international merchandise, and also against non-Muslims. Ushr also remain subject to the illicit goods brought non-Muslim citizens, as khamr (Huda et al, 2011). Although these instruments based regulation can only be done by the central government, but the increase and decrease in revenue will remain affected the local government in the form of profit sharing.

The other income instruments that still relevant with the current administration are Aml-Fadla. Aml-Fadla is an estate that no heirs can be referenced in the same case if it happened in Indonesia. Withdrawal of corruption is also very relevant property to be used as a source of reference, considering that Indonesia has a high level of corruption by various international agencies assessment. Transparency International in 2010 establishes Indonesia is the most corrupt of 16 investment destinations businesses in Asia Pacific. Corruption not only violates the moral and religious, but very detrimental to the business world, because it raises the cost of high economic and legal uncertainty.

Nawaib is a tax imposed on the rich Muslim countries due to lack of funds due to the long war and spent the state treasury, at the time of the Prophet Muhammad nawaib government never practiced in the Battle of Tabuk. The spirit is still very relevant nawaib applied in today's modern government when a state of emergency, such as a catastrophe. Moreover, people are very rich in Indonesia amounted to minority and majority control of existing wealth, then they are very reasonable assume obligations in times of national emergencies.

Voluntary instrument in the form of donation, Sadaqah and endowments are also very relevant to being involved in economic development. Basically realize the public interest is the collective responsibility of government and society. Because Islam requires a community to make a series of arrangements that can ensure the fulfillment of the needs of all members of society. There are various types of needs 
in the community. Some of them can be met by the community itself. Part of the others can be met by the government (Huda et al, 2012). Although voluntary, this instrument also has contributed enormously, especially when the sector shall not be sufficient to fund the programs and activities of the state. Even the amount of the voluntary instrument is much more comprehensive indicator to measure the responsibility and community participation in the life of the nation. Many productive assets such as luxury hotels, hospitals, schools superior, even shop funded by endowment funds, where the results of the profits earmarked for the benefit of the people. Endowments powerful productive by reducing personal mastery will give birth conglomerates are prone to problematic because of greed. Productive Endowments also effectively prevent the ownership control of the economic sectoreither by adverse foreign and private lives of many people in a country, which in turn can reduce the rate of inflation.

Sources of financing in the form of Islamic state in principle can be flow creating more equity than debt creating flows (Huda, 2012). Compared with the debt in conventional, the cooperation schemes in the form of equity participation look more constructive, proportionate and fair as a source of financing, because there are cost and risk sharing (Iskandar, 2010). Other types of financing sources are Sukuk. Sukuk is a financial instrument that is very strategic for local governments. Sukuk must be based on an underlying asset, the lease contract or for the results as a basis of calculation. Sukuk for local projects / government could also increase the role of the community to actively participate in the development and ownership of the fund the project, it is very effective in reducing the foreign debt and foreign dependence.

\section{Conclusion}

Fiscal policy in the Islamic countries aiming to develop a society based on the distribution of wealth with the content of the material and spiritual values equitably. Islamic law on state finances is very elastic so it can be expanded to meet the requirements modern times. All income instruments from Islamic countries is very relevant to be applied in the central government and local governments in Indonesia, except ghanimah instruments and jizya. Ghanimah irrelevant applied because there is no source of income of the spoils of war in the present. Similarly, is the Jizya instruments is not relevant to be applied today. Because Indonesian government don't imposed the tax that based on the individual religion. Relevance application of all the instruments is needed to be adjusted nomenclature and connectivity with existing regulations. The application does not have to be exclusive and fixated on the label of Islam, but should be focused on the exploration of values and universal 
benefits that have been attached to almost all Islamic state income instruments.

Load the value and benefits that are universal and are needed to strengthen the fiscal capacity of central and local government should not be hampered its application for nomenclature and regulatory constraints. The executive and the legislature should be proactive in addressing the constraints and the impasse in order to achieve the objectives and benefits of a more strategic and wide. Patterns of government policy in the Islamic state that can be used as a reference or normative complementary sources, to strengthen the ability of national and local government fiscal in Indonesia, such as: the instrument of charity, kharaj, ushr, donation, endowment, natural resource management with rikaz system, and other income derived from the state of corporate profits, state wealth and asset management, amwal al-fadla, withdrawal of illegal assets / corruptors, expiation and sacrifices.

\section{References}

Ahmad, A. \& T. Khan. 1997. Islamic Financial Instruments For Public Sector Resource Mobilization. Seminar Proceedings No.39. Jeddah: Islamic Development Bank Islamic Research and Training Institute.

Al Arif, M.N.R. 2010. Teori Makroekonomi Islam. Bandung: Alfabeta.

Gulaid, M.A. \& M.A. Abdullah. 1995. Reading In Public Finance. Jeddah: Islamic Development Bank Islamic Research and Training Institute.

Huda, N. et.al. 2012. Keuangan Publik Islami: Pendekatan Teoritis dan Sejarah. Jakarta: Kencana.

Huda, N. \& A. Muti. 2011. Keuangan Publik Islami Pendekatan Al-Kharaj: Imam Abu Yusuf.Bogor: Ghalia Indonesia.

Inayah, G. 2003. Teori Komprehensif tentang Zakah dan Pajak. Yogya: PT Tiara Wacana.

Johari, F. \& P. Ibrahim. 2010. The Dynamism in The Implementation of Al-Kharaj During The Islamic Rule. Shariah Journal, Vol 18, No.3 (2010), pp. 629658.

Moleong. L.J. 2002. Metode Penelitian Kualitatif. Bandung: PT Rosdakarya.

Qardhawy, Y. 1988. Hukum Zakah. Jakarta: Pustaka Litera Antar Nusa.

Sugiyono. 2013. Memahami Penelitian Kualitatif. Bandung: Alfabeta

Suharto, U. 2005. Kitabal-Amwal: Abu Ubayd's Concept of Public Finance. Malaysia: International Institute of Islamic Thought and Civilization (ISTAC), International Islamic University Malaysia (IIUM).

Suharto, U. 2009. Zakah Sebagai Lembaga Keuangan Publik Khusus: Refleksi Kitabal Amwal Karya Abu Ubaid (W 838 M). Jurnal Pemikiran dan Gagasan - Vol II 2009, pp. 15-30. 


\section{ABOUT AUTHORS}

Abdul Razak Abdul Hadi is the lecture from University of Kuala Lumpur, Malaysia. He also as a researcher on Islamic economics and finance studies.

Any Setianingrum is doctoral student of Islamic Economics Department at University of Airlangga. She also as a researcher on Islamic economics and finance studies.

Burhanuddin Yusuf is the lecture at Syarif Hidayatullah State Islamic University Jakarta. He completedly his doctoral degree at State University of Jakarta (UNJ). Also as a researcher on Islamic Economics and Finance studies.

Chandra Warsito is the lecture of IAIN Purwokerto. He also as a researcher on Islamic economics and finance studies.

Erika Amelia is the lecture of Syarif Hidayatullah State Islamic University Jakarta. She completedly her master degree at University of Indonesia.

Kurniasih finished her bachelor degree ats Syarif Hidayatullah State Islamic University Jakarta. Now she as a researcher on Islamic economics and finance studies.

Mahmud is a Lecturer at the STIA Al Karimiyyah Sumenep. Expertise in Islamic Education studies.
Muniaty Aisyah is the lecture at Syarif Hidayatullah State Islamic University Jakarta. Shee completedly her doctoral degree at University of Trisakti. Now she as a Head of Management Department at Syarif Hidayatullah State Islamic University Jakarta

Nurul Huda is a lecture at Faculty of Economic University of Yarsi. Finished his master degree at University of Indonesia, and Doctoral degree at University of Airlangga. Now he as a Head of Master of Management Department University of Yarsi. Also as a researcher on Islamic economics and finance studies.

Rachmad Hidayat is a lecturer at the Industrial Engineering Department, University of Trunojoyo Madura.

Rizky Andriati finished the bachelor degree at Jakarta State University (UNJ) and master degree at Middle Eastern and Islamic Studies from University of Indonesia. Also as a reporter on Islamic Economics and Finance.

Rizqon Halal Syah Aji, is the lecture at Syarif Hidayatullah State Islamic University Jakarta. He completedly his bachelor degree at Islamic University of Asy-Syafiiyah, and master degree at University of Indonesia. Now he as a Head of Computation Laboratorium at Faculty Economics and Business Syarif Hidayatullah State Islamic University Jakarta. 
Sabarudin Akhmad is a lecture at the Industrial Engineering Department at University of Trunojoyo. He also as a researcher on industrial engineering studies.
Tulus Suryanto is the lecture of IAIN Raden Intan Lampung Indonesia. He also as a researcher on Islamic economics and finance studies. 


\section{ARTICLES AND AUTHORS}

Vol. VII, No. 1, January 2015

\begin{tabular}{|c|c|c|c|}
\hline No & Name & Title & Note \\
\hline \multirow[t]{6}{*}{1} & Titi Dewi & Mapping and Correlation & Lecture of Syarif \\
\hline & Warninda \& M. & Analysis of Efficiency and & Hidayatullah State Islamic \\
\hline & Nadratuzzaman & Profitability: The Case of & University Jakarta. Also \\
\hline & & & as a researcher on Islamic \\
\hline & & & Economics and Finance \\
\hline & & & Studies \\
\hline \multirow[t]{6}{*}{2} & Euis Amalia \& & Evaluating The Models & Lecture of Syarif \\
\hline & Mahmudah Atiqah & of Sharia Microfinance & Hidayatullah State Islamic \\
\hline & & in Indonesia: Analytical & University Jakarta. Also \\
\hline & & Network Process & as a researcher on Islamic \\
\hline & & Approach & Economics and Finance \\
\hline & & & Studies \\
\hline \multirow[t]{3}{*}{3} & Hardius Usman & The Role of Religious & Lecture of Middle East and \\
\hline & & Norm on Selecting the & Islamic Studies Department \\
\hline & & Islamic Bank & at University of Indonesia. \\
\hline \multirow[t]{6}{*}{4} & Suryani \& & A Developing Model of & Lecture of STAIN \\
\hline & Hendryadi & Relationship Between & Malikussaleh and Lecture \\
\hline & & Service Quality, Customer & of At-Thahiriyah Islamic \\
\hline & & Satisfaction, Loyalty, and & University Jakarta \\
\hline & & Word of Mouth in Islamic & \\
\hline & & Banking & \\
\hline \multirow[t]{5}{*}{5} & Yoghi Citra & Macroeconomic Variable & Lecture of Syarif \\
\hline & Pratama & and Its Influence & Hidayatullah State Islamic \\
\hline & & on Performance of & University Jakarta \\
\hline & & Indonesian Islamic & \\
\hline & & Banking & \\
\hline \multirow[t]{5}{*}{6} & Indah Mulia Sari, & Factors That Influenced & Lecture of SEBI Islamic \\
\hline & Hendro Wibowo, & People to Become Islamic & Business School. Also as \\
\hline & \& Edy Suprapto & Bank Customer: a Study & a researcher on Islamic \\
\hline & & on Kancana Villagers & Economics and Finance \\
\hline & & & Studies \\
\hline \multirow[t]{5}{*}{7} & Irfan Syauqi Beik & Construction of CIBEST & Lectures of Agricultural \\
\hline & \& Laily Dwi & Model As Measurement & Institute Bogor (IPB). Also \\
\hline & Arsyianti & of Poverty and Welfare & as a researcher at CIBEST \\
\hline & & Indices From Islamic & \\
\hline & & Perspective & \\
\hline
\end{tabular}




\begin{tabular}{|c|c|c|c|}
\hline 8 & $\begin{array}{l}\text { M. Sabri Haron, } \\
\text { Riki Rahman \& } \\
\text { Bayu T Possumah }\end{array}$ & $\begin{array}{l}\text { The Assesment of } \\
\text { Inclusiveness Principle of } \\
\text { Malaysian New Economic } \\
\text { Model: Maqashid } \\
\text { Syar'iyyah Perspective }\end{array}$ & $\begin{array}{l}\text { Lecturer at Pusat Citra } \\
\text { Universiti, Universiti } \\
\text { Kebangsaan Malaysia } \\
\text { (UKM). Also researcher } \\
\text { on Islamic Economics and } \\
\text { Finance Studies }\end{array}$ \\
\hline 9 & Abdul Hamid & $\begin{array}{l}\text { The Impact of Spin-off } \\
\text { Policy To The Profitability } \\
\text { on Indonesian Islamic } \\
\text { Banking Industry }\end{array}$ & $\begin{array}{l}\text { Lecture of Syarif } \\
\text { Hidayatullah State Islamic } \\
\text { University Jakarta. }\end{array}$ \\
\hline 10 & $\begin{array}{l}\text { Zuhairan Y. Yunan } \\
\text { \& Mia Rahmasari }\end{array}$ & $\begin{array}{l}\text { Measurement of Shariah } \\
\text { Stock Performance } \\
\text { Using Risk Adjusted } \\
\text { Performance }\end{array}$ & $\begin{array}{l}\text { Lecture of Syarif } \\
\text { Hidayatullah State } \\
\text { Islamic University Jakarta. } \\
\text { Researcher at University of } \\
\text { Prof. Dr. Hamka (Uhamka) }\end{array}$ \\
\hline
\end{tabular}

Vol. VII, No. 2, July 2015

\begin{tabular}{|c|c|c|c|}
\hline No & Name & Title & Note \\
\hline \multirow[t]{4}{*}{1} & Wiwiek Rabiatul & The Impact of Financial & Lecture of University of \\
\hline & Adawiyah & Liberalization on Islamic & Jenderal Soedirman. Also as \\
\hline & & Bank's Efficiency in & a researcher on economics \\
\hline & & Indonesia & and finance studies \\
\hline \multirow[t]{6}{*}{2} & Rachmad Hidayat, & Effects of Service Quality, & Lecture of Industrial \\
\hline & Sabarudin & Customer Trust, and & Engineering Department \\
\hline & Akhmad, & Customer Religious & University of Trunojoyo. \\
\hline & Machmud & Commitment on & Lecture of Islamic Education \\
\hline & & Customer Satisfaction and & Department, STI Al- \\
\hline & & Loyalty of Islamic Banks & Karimiyah \\
\hline \multirow[t]{6}{*}{3} & Muniaty Aisyah & $\begin{array}{l}\text { in East Java } \\
\text { Peer Group Effects on }\end{array}$ & Lecture of Syarif \\
\hline & & Moslem Consumer's & Hidayatullah State Islamic \\
\hline & & Decision To Purchase & University Jakarta. Also \\
\hline & & Halal-Labeled Cosmetics & as a researcher on Islamic \\
\hline & & & Economics and Finance \\
\hline & & & Studies \\
\hline \multirow[t]{6}{*}{4} & Rizqon Halal Syah & The Intellectural Capital & Lecture of Syarif \\
\hline & Aji \& Kurniasih & Effect on Financial & Hidayatullah State Islamic \\
\hline & & Performances at Islamic & University Jakarta. Also \\
\hline & & Insurance & as a researcher on Islamic \\
\hline & & & Economics and Finance \\
\hline & & & Studies \\
\hline \multirow[t]{3}{*}{5} & Tulus Suryanto \& & Capital Market & Lecture of IAIN Raden \\
\hline & Abd Razak Abdul & Integration: Palestine and & Intan Lampung. Lecture of \\
\hline & Hadi & Isreaeli Experience & University of Kuala Lumpur \\
\hline
\end{tabular}




\begin{tabular}{|c|c|c|c|}
\hline 6 & $\begin{array}{l}\text { Rizky Andriati \& } \\
\text { Nurul Huda }\end{array}$ & $\begin{array}{l}\text { The Effect of Productive } \\
\text { Zakah Mentoring on The } \\
\text { Wealth of Mustahik }\end{array}$ & $\begin{array}{l}\text { Lecture at University of } \\
\text { Yarsi. Researcher on Islamic } \\
\text { Economics and Finance } \\
\text { Studies }\end{array}$ \\
\hline 7 & Chandra Warsito & $\begin{array}{l}\text { The Image of Financial } \\
\text { Institution as Islamic } \\
\text { Bank in Mediation Service } \\
\text { Quality and Customer } \\
\text { Satisfaction on Customer } \\
\text { Loyalty in Purwokerto }\end{array}$ & $\begin{array}{l}\text { Lecture at IAIN Purwokerto. } \\
\text { Researcher on Islamic } \\
\text { Economics and Finance } \\
\text { Studies }\end{array}$ \\
\hline 8 & Erika Amelia & $\begin{array}{l}\text { Financial Ratio and Its } \\
\text { Influence to Profitability } \\
\text { in Islamic Banks }\end{array}$ & $\begin{array}{l}\text { Lecture of Syarif } \\
\text { Hidayatullah State Islamic } \\
\text { University Jakarta. Also } \\
\text { as a researcher on Islamic } \\
\text { Banking studies }\end{array}$ \\
\hline 9 & Burhanuddin Yusuf & $\begin{array}{l}\text { Human Resources } \\
\text { Development of } \\
\text { Sharia Banking: } \\
\text { Phenomenological } \\
\text { Approach }\end{array}$ & $\begin{array}{l}\text { Lecture of Syarif } \\
\text { Hidayatullah State Islamic } \\
\text { University Jakarta. Also } \\
\text { as a researcher on Islamic } \\
\text { Economics and Finance } \\
\text { Studies }\end{array}$ \\
\hline 10 & Any Setianingrum & $\begin{array}{l}\text { Application of Pattern } \\
\text { of Islamic State Revenue } \\
\text { Policy to Improve The } \\
\text { Ability of Indonesia's } \\
\text { Fiscal }\end{array}$ & $\begin{array}{l}\text { Doctoral student at Islamic } \\
\text { Economics Department at } \\
\text { University of Airlangga }\end{array}$ \\
\hline
\end{tabular}


INDEX

Analytical network process

ANOVA

BOPO

Capital adequacy ratio

Capital market integration

Case study analysis

CIBEST model

Contemporary group

Consumer's behavior

Customer's loyalty

Customer's satisfaction

Customer's trust

Data envelopment analysis

Deposit margin

Dog quadrant

Dummy variable

Efficiency

Finance

Financial liberalization

Financial ratio

Financing to deposit ratio

Fiscal

Halal-labeled

Historical analysis

Human resources

Human resources management

Image

Inclusiveness principles

Intellectual capital

Islamic bank

Islamic insurance

Islamic rural bank

Loyalty

Macroeconomic variables

Management
Maqashid shariah

Marketing

New economic model

Non performing finance

Partial least square

Peer group

Performance

Phenomenological approach

Poverty

Profitability

Prosperity

Question-mark quadrant

Religious commitments

Religious norms

Revenue

Risk adjusted performance

Saving behavior

Service quality

Shariah compliance

Shariah microfinance

Shariah stock

Sleeper quadrant

Spin-off

Star quadrant

Stock performance

Strategy

Structural equation model

Traditional group

Vector auto regressive

Vector error correction model

Welfare indices

Word of mouth

Zakah mentoring 


\section{AL-IQTISHAD \\ Journal of Islamic Economics}

\section{GUIDANCE FOR WRITING IN Journal of Al-Iqtishad}

1. The manuscripts represent academic research in Islamic economics and Finance discipline.

2. Upon the publication of the manuscript, the author should provide a letter states that the manuscripts have never been, or under consideration to be, published in other journal publications.

3. Structure of the manuscripts

a. Title. The title should be short, clear, and informative, but does not exceed 9 words.

b. Author's names and institutions. The author's names should be accompanied by the author's institutions and email addresses, without any academic titles and/or job title.

c. Abstract and keywords. The abstract should be less than 150 words. The key words should be 2 to 5 phrases.

d. Introduction. This section explains the backround of the study, and aims of the manuscripts. It should be written without numbers and/or pointers.

e. Literature Review. This section explains the theoretical framework that used on this research, a review on the previous research in the area.

f. Methods. This section describes the tools of analysis along with the data and their sources.

g. Discussion. This section explains the results of the study.

h. Conclusions. This section concludes and provides policy implications, if any, of the study.

i. References. This section lists only the papers, books, or other types of publications referred in the manuscript.

4. The authors should provide an index of subject, namely the specific terms in the manuscript. The authors should also provide the index of authors, namely the key authors of papers referred in the manuscript. Please write the family name followed by the given name.

5. Estimation result from a software package is not allowed to be directly presented in the paper. They should be presented in equations with the appropriate estimation results.

6. Table format should contains only heading and contents. Please provide the top and bottom lines, along with the line(s) that separate the heading and the contents. Example:

Table 1. The Growth of Third Party Fund, Financing and Asset (Billion rupiah)

\begin{tabular}{lcccccc}
\hline & $\mathbf{2 0 0 9}$ & $\mathbf{2 0 1 0}$ & $\mathbf{2 0 1 1}$ & $\mathbf{2 0 1 2}$ & $\mathbf{2 0 1 3}$ & $\mathbf{2 0 1 4}$ \\
\hline Fundraising & 52.271 & 76.036 & 115.415 & 147.512 & 174.018 & 186.608 \\
Financing & 46.886 & 68.181 & 102.655 & 147.505 & 179.284 & 187.886
\end{tabular}


Asset

$\begin{array}{llllll}66.090 & 97.519 & 145.467 & 195.018 & 229.557 & 244.197\end{array}$

Source: Islamic banking statistics, Bank of Indonesia

7. Acknowledgment, if any, should be written as the foot-note of the manuscript's title.

8. The manuscript is prepared in a quarto paper, single-sided, and double-space format. A new paragraph should start 5 characters from the left margin, using 12-size, times-newromans font type.

9. The manuscript is written in proper English, either British or American English, but not the combination of both, except for special editions.

10. The manuscript should be in no less than 25 pages long.

11. The top and bottom margins are 1 inch.

12. The title is written using capital letters of 14 font size, centre position.

13. Sub titles are written using capital letters, started from the left margin.

14. Sub of sub titles are written using capital letters only at the beginning of each word except for connecting words. They should be started from the left margin.

15. References should be those of the last ten years publication, unless they are key references.

16. Citation in the text body should be written using the family name and years of publication. Example:

a. Hill (2001) suggests that the objective of depreciation ....

b. According to Kotter (1867), intra industry trade can be ...

c. Wagner (in McCain, 1982) states that ...

d. The definition of flypaper effect is ... (Wagner, 1976).

17. Tables and figures should be presented as follows:

a. The name of tables and figures should follow a numbering system (Arabic numbering system). The names of the tables and figures are on the top and bottom parts of the tables, respectively.

b. The tables and figures should provide the source of information, if any, at the bottom part of both.

18. References should be written in alphabetical order, without any number. They should be written using the following criteria:

a. For books, the format should follow the following example:

Al Arif, M. N. R. 2010. Dasar-dasar Pemasaran Bank Syariah. Bandung: Alfabeta.

b. For papers that are part of a book, the format should follow the following example:

Bahl, R. 2000. How to Design a Fiscal Decentralization. in Sahid, Y. (eds.), Local Dynamics in an Era of Globalization, 25-26, London: Oxford University Press.

c. For journal/magazine papers, the format should follow the following example:

Al Arif, M. N. R. 2012. Efek Multiplier Wakaf Uang dan Pengaruhnya Terhadap Program Pengentasan Kemiskinan. Jurnal Asy-Syir'ah Fakultas Syariah UIN Sunan Kalijaga Yogyakarta, Vol. 46, No. 1, Januari 2012, hlm. 10 - 12.

d. For internet references, the format should follow the following example:

Kharlie, Ahmad Tholabi. 2006. "Formalisasi Syariat Islam, Mengapa Tidak?”, http// www.ahmadtholabi.wordpress.com, accesed on 17 Maret 2014

e. For magazine, the format should follow the following example: Asa, Syu'bah. 2004 "Pengantin Darah", dalam Tempo, No. 30/XXX111/20, 20 September 2004 
19. Transliteration guidance (from Arabic to latin)

\begin{tabular}{|c|c|c|}
\hline \multicolumn{3}{|c|}{ Consonant } \\
\hline$(1)=a$ & $(j)=\mathrm{z}$ & (ق) $=\mathrm{q}$ \\
\hline (ب) = b & = s & (ك) $=\mathrm{k}$ \\
\hline (ت) $=t$ & (ش) = sy & $(\mathrm{J})=1$ \\
\hline$(\dot{ث})=\mathrm{ts}$ & $(ص)=s h$ & $(\rho)=m$ \\
\hline$(\tau)=j$ & (ض) = dh & (ن) $=\mathrm{n}$ \\
\hline$(\tau)=\underline{\mathrm{h}}$ & $(b)=$ th & $(g)=w$ \\
\hline$(\dot{\tau})=\mathrm{kh}$ & $($ (ظ) $=\mathrm{zh}$ & (०) $=\mathrm{h}$ \\
\hline$(2)=d$ & $(\varepsilon)={ }^{\prime}$ & $(\varepsilon)={ }^{\prime}$ \\
\hline$(\dot{\Sigma})=\mathrm{dz}$ & $(\dot{\xi})=\mathrm{gh}$ & (s) = y \\
\hline()$=r$ & (ف) = f & $(\dot{0})=\underline{t}$ \\
\hline
\end{tabular}

\begin{tabular}{|c|c|}
\hline Short Vocal & Long Vocal \\
\hline$=\mathrm{a}$ & $(\mathrm{I}-)=\hat{\mathrm{a}}$ \\
\hline $\mathrm{i}$ & $(\mathrm{s}-)=\hat{\mathrm{i}}$ \\
\hline $\mathrm{i}$ & $(\mathrm{s}-)=\hat{\mathrm{u}}$ \\
\hline
\end{tabular}

\begin{tabular}{|c|c|}
\hline Diftong & Pembauran \\
\hline (أو) = aw & $(\mathrm{JI})=\mathrm{al}$ \\
\hline (أي) = ay & (الش) al-sy \\
\hline & (وال) = wa al- \\
\hline
\end{tabular}

20. The manuscript in microsoft word should be sent to editor.iqtishad@yahoo.com

21. A brief CV that records full name, academic title, institution, telephone, fax and mobile number should accompany the manuscript.

22. The decision of the manuscript are:
a. Accepted without revision, or
b. Accepted with minor revision, or
c. Accepted with major revision, or
d. Rejected.

23. Upon the publication of the manuscript in the journal, the author will receive a publication proof number and 3 off-prints. 